\title{
The control of trunk Hox specificity and activity by Extradenticle
}

\author{
Hyung Don Ryoo and Richard S. Mann ${ }^{1}$ \\ Department of Biochemistry and Molecular Biophysics, Columbia University, New York, New York 10032 USA
}

\begin{abstract}
We characterize a 37-bp element ( $f k h[250]$ ) derived from the fork head ( $f k h)$ gene, a natural target of the Hox gene Sex combs reduced (Scr). In vitro, Scr cooperatively binds to this DNA with the Hox cofactor Extradenticle (Exd), and the activation of this enhancer in vivo requires Scr and exd. Other Hox/Exd heterodimers do not activate this element in vivo and do not bind this element with high affinity in vitro. The amino-terminal arm of the Scr homeodomain is crucial for the specific activation of this element in vivo. By mutating two base pairs within this element, we can convert the Scr/Exd-binding site to a Hox/Exd consensus site that binds several different Hox/Exd heterodimers. This element, fkh $\left[250^{\text {con }}\right]$, is activated by Scr, Antennapedia (Antp), and Ultrabithorax (Ubx) but repressed by abdominal-A (abd-A). We also show that Scr and Exd are only able to activate the fkh[250] element during the early stages of embryogenesis because, by stage 11, Scr negatively regulates the gene homothorax $(h t h)$, which is required for the nuclear localization of Exd. These results suggest that Exd is a specificity cofactor for the trunk Hox genes, and that the control of Exd subcellular localization is a mechanism to regulate Hox activity during development.
\end{abstract}

[Key Words: Extradenticle; Pbx; Hox specificity; cooperative DNA binding]

Received April 7, 1999; revised version accepted May 20, 1999.

During animal development, the Hox genes are required to interpret positional information and confer the appropriate fate to each cell (for review, see McGinnis and Krumlauf 1992). Hox genes encode homeodomain proteins that transcriptionally regulate downstream genes that ultimately control morphology (for review, see Graba et al. 1997). Most Hox proteins share a high degree of sequence homology within their homeodomains, and as a consequence have similar DNA-binding properties (Ekker et al. 1994). In vivo, however, Hox proteins instruct unique morphologies, suggesting that they bind and regulate distinct, though likely overlapping, sets of target genes. The disparity between these in vitro and in vivo observations implies the existence cofactors that contribute to the functional specificity of Hox proteins in vivo.

In Drosophila, extradenticle (exd) encodes a cofactor of the Hox proteins (Mann and Chan 1996). exd and its vertebrate homologs, the $p b x$ genes, encode homeodomain proteins of the PBC class (Burglin and Ruvkun 1992; Rauskolb et al. 1993). Like the Hox genes, exd is required for anterior-posterior (A-P) patterning in both the embryo and adult of Drosophila (Peifer and Wieschaus 1990; Rauskolb and Wieschaus 1994; GonzalezCrespo and Morata 1995; Rauskolb et al. 1995). exd is required in most segments along the $\mathrm{A}-\mathrm{P}$ axis, suggesting a genetic interaction with many Hox genes. Consis-

${ }^{1}$ Corresponding author.

E-MAIL rsm10@columbia.edu; FAX (212) 305-7924. tent with this idea, Hox target genes such as teashirt and decapentaplegic ( $d p p)$ in the visceral mesoderm and labial (lab) in the endoderm also require exd for their expression (Chan et al. 1994, 1996; Rauskolb and Wieschaus 1994). At the molecular level, Exd and Hox proteins cooperatively bind as a heterodimer to a 10-bp DNA sequence, TGATNNATNN, and such binding sites have been identified in the autoregulatory enhancers from the Hox genes Hoxb-1, 1ab, and Deformed ( $D f d$ ) (Pöpperl et al. 1995; Mann and Chan 1996; Chan et al. 1997; Grieder et al. 1997; Passner et al. 1999; Piper et al. 1999|. Another interesting characteristic of Exd is that its nuclear localization is regulated during development and requires the direct interaction with another homeodomain protein encoded by the gene homothorax (hth) (Mann and Abu-Shaar 1996; Rieckhof et al. 1997; Pai et al. 1998; Abu-Shaar et al. 1999).

Although it is clear that Exd is a Hox cofactor, two models have been suggested to describe Exd's role in Hox function. The first model proposes that Exd helps the Hox proteins achieve DNA-binding specificity in vivo. Such a role for Exd was initially reasoned from the phenotype of exd mutant embryos, in which the Hox proteins appear to be expressed normally but function incorrectly (Peifer and Wieschaus 1990; Chan et al. 1994; Rauskolb et al. 1995). Evidence supporting this model comes in part from in vitro studies. First, because Hox/ Exd heterodimers bind a 10-bp sequence, such binding sites will be less frequent in the genome than the typical 6-bp sequence bound by Hox monomers (Mann and 
Chan 1996). In addition, however, Exd may exert a more profound affect on Hox specificity: It has been shown that Hox proteins that normally bind the same sequence as monomers prefer to bind different sequences as Hox/ Exd heterodimers (Chan et al. 1994; Chan and Mann 1996; Chang et al. 1996; Shen et al. 1996; Phelan and Featherstone 1997; Wilson and Desplan 1999|. Thus, at least in vitro, different Hox/Exd heterodimers bind subtly different Hox/Exd-binding sites. This property suggests that Exd may help to distinguish between the functions of different Hox proteins in vivo, by selectively enhancing the DNA binding of one Hox protein over another. In support of this idea, there is one case in which different Hox/Exd-binding sites were shown to direct distinct Hox-dependent expression patterns in vivo. In that study, a Labial/Exd-responsive enhancer could be converted to a Dfd/Exd-responsive enhancer by changing only two basepairs in a Hox/Exd-binding site (Chan et al. 1997). However, although the change in in vivo specificity was clear, this experiment had several limitations. First, the modified binding site was not specific for Dfd/Exd heterodimers; other Hox/Exd heterodimers, for example, Lab/Exd, also bound this sequence in vitro. Second, making the same alteration in another Lab/Exd-binding site present within a lab autoregulatory enhancer did not change its specificity to Dfd (Grieder et al. 1997). Third, the change of specificity from Lab to another Hox protein could represent a special case, because the Lab homeodomain is one of the most diverged among the Hox family.

The second model for Exd function proposes that instead of acting as a specificity cofactor, Exd forms heterodimers with all Hox proteins and changes their regulatory properties, from transcriptional repressors to activators (Biggin and McGinnis 1997; Pinsonneault et al. 1997; Li et al. 1999). Consistent with this model, in vivo cross-linking experiments show that homeodomain proteins are bound to many genes in the Drosophila genome (Walter et al. 1994; Liang and Biggin 1998; Carr and Biggin 1999). However, this binding has not been shown to be functional, and is not unexpected for DNA-binding proteins with low sequence specificity. Additional support for this model stems from in vivo experiments in which the activity of a Dfd monomer-binding site was compared with a Dfd/Exd heterodimer-binding site (Li et al. 1999). In these experiments it was shown that a Dfd/ Exd heterodimer was a more potent transcriptional activator than a Dfd monomer. Thus, at least for these artificial binding sites, it appears that Exd provided or revealed a latent activation domain in Dfd.

The two models for Exd function are not mutually exclusive; Exd could be providing both additional specificity and activator functions to the Hox proteins. Nevertheless, if Exd does function as a specificity cofactor for most Hox proteins, it should be possible to demonstrate that the presence of an Exd-binding site is important for distinguishing between the functions of Hox proteins that have very similar homeodomains, for example those of the Antennapedia (Antp) class. A critical test of this idea would be to demonstrate such a role for Exd on a natural Hox/Exd-binding site. In Drosophila, the Antp class Hox genes Sex combs reduced (Scr), Antp, Ultrabithorax $(U b x)$, and abdominal-A $(a b d-A)$ have very similar homeodomains and are expressed in the thoracic and abdominal (trunk) segments. However, to date no Hox target genes have been described that are directly coregulated by Hox and Exd proteins in the trunk ectoderm of the fly. Here, we characterized a Hox/Exd-binding site present in an enhancer from the fork head ( $f k h)$ gene, a natural target of Scr (Panzer et al. 1992; Andrew 1998). We show that Exd acts as a specificity cofactor for Scr on this element, and that Exd can also act as a cofactor for other Antp class Hox proteins on a variant of this Hox/Exd-binding site. Thus, Exd is a specificity cofactor for this class of Hox proteins.

\section{Results}

A 37-bp fkh enhancer element is regulated by Scr and exd

The fkh gene of Drosophila is expressed in the salivary placode, the primordia of the embryonic salivary gland (Panzer et al. 1992; Andrew 1998). Salivary placodes are distinct regions of columnar epithelial cells formed at the ventral side of parasegment (PS) 2 during stage 11 . fkh-expressing cells eventually invaginate to form the embryonic salivary gland. Scr is one of the genes required for $f k h$ activation and salivary gland formation (Panzer et al. 1992). A 5-kb enhancer from $f k h$ drives expression of a reporter gene in a pattern identical to the Fkh protein (Kuo et al. 1996; Fig. 1D,E). Within this 5-kb enhancer there is a $37-b p$ element $(\mathrm{fkh}[250])$ including the sequence, AGATTAATCG, that is related to the Hox/Exd consensus-binding site (Fig. 1A). To test the activity of this element, four copies of fkh[250] were cloned upstream of a minimal promoter driving lacZ, and transgenic flies were generated with this reporter gene, fkh[250]-lacZ. On immunostaining for $\beta$-galactosidase ( $\beta$-gal), expression was observed in PS 2 (Fig. $1 F, H)$. Double staining for Scr and $\beta$-gal confirmed that $f k h[250]-l a c Z$ was expressed in a ventral subset of $\mathrm{Scr}^{+}$ cells (Fig. 1F,G). Weaker staining unrelated to the endogenous $f k h$ pattern was also detected along the lateral sides of these embryos.

The presence of a putative Hox/Exd-binding site suggests that fkh[250] could be activated by an Scr/Exd heterodimer. Consistent with this idea, Scr and Exd are colocalized in PS 2 nuclei at the time that $f k h$ expression initiates (Fig. 1B-E). To obtain additional evidence, we examined $f k h[250]-l a c Z$ expression in $S c r$ and exd mutant embryos. Most of the $\beta$-gal staining was abolished in Scr- embryos, although the weak lateral staining remained (Fig. 1I). To test for a requirement for exd, which is expressed maternally and zygotically (Peifer and Wieschaus 1990; Rauskolb et al. 1993), exd $d^{-}$germ-line clones were generated in females that were crossed to males containing the $f k h[250]-1 a c Z$ reporter gene. $\beta$-Gal expression was not observed in exd maternal-, zygotic ${ }^{-}$ 
Figure 1. The fkh[250] element includes a potential Hox/Exd-binding site and requires $\mathrm{Scr}$ and exd for its activation in embryos. (A) The sequence of the Hox/Exdbinding sites within $\mathrm{fkh}[250]$ and $\mathrm{fkh}\left[250^{\mathrm{con}}\right]$ are compared with the consensus-binding site. The two differences between fkh[250] and fkh[250 $\left.{ }^{\text {con }}\right]$ (basepairs 6 and 9) are underlined, whereas mutations in the Exd or Hox half-sites are indicated with lowercase letters. $(B, C)$ Fluorescent images of a stage-10 embryo (lateral view of PS 2 region) stained for Exd (green) and Scr (blue). $(D, E)$ Fluorescent images of a stage-10 fkh-lac $Z$ embryo (lateral view of PS 2 region) stained for $\beta$-gal (red) and Scr (blue). At this stage, Exd is nuclear in all $\mathrm{Scr}^{+}$cells, and a subset of $\mathrm{Scr}^{+}$cells begin to express $f k h-l a c Z$. $(F, G)$ Fluorescent images of a wild-type fkh[250]-lacZ embryo stained for $\beta$-gal (red) and Scr (blue). Only a subset of the $\mathrm{Scr}^{+}$cells express $f k h[250]-$ lacZ. $(H, I, J)$ Wild-type $(H), \operatorname{Scr}^{-}(I)$, and ex $d^{\mathrm{mat}^{-}, \mathrm{yyg}^{-}}(J)$ fkh[250]-lacZ embryos histochemically stained for $\beta$-gal (brown). PS 2 expression is absent in the $\mathrm{SCr}^{-}$embryo but the lateral staining remains. All detectable reporter gene expression is absent in the exd $d^{\text {mat }^{-}, \text {zyg }^{-}}$embryo. (K) Fluorescent image of an exd ${ }^{\text {mat }^{-}, \mathrm{zyg}^{-}}$; fkh[250]-lacZ em-

bryo in which Scr was ubiquitously ex-pressed, and stained for $\beta$-gal (red) and Scr (blue). Ectopic Scr was not able to activate $f k h[250]-l a c Z$ in these embryos. $(L, M) f k h[250]^{e x d}-1 a c Z(L)$ or $f k h[250]^{S c r}-1 a c Z(M)$ embryos histochemically stained for $\beta$-gal (brown). Mutation of the Exd half-site $(L)$ or Scr half-site $(M)$ abolishes PS 2 expression. $(F-M)$ Ventral views of $\sim$ stage 10 embryos, with anterior to the left.

$\left(\right.$ ex $d^{\text {mat }^{-}, \text {zyg }^{-}}$) embryos (Fig. 1J). Because Scr expression is diminished in exd $d^{-}$embryos (L. Komenda and S. Beckendorf, pers. comm.), we artificially provided high levels of Scr in exd $d^{\text {at }^{-}, \mathrm{zyg}^{-}}$embryos using a heat shock-Scr (HS:Scr) transgene. Despite high levels of Scr, we were unable to detect any $f k h[250]-1 a c Z$ expression in these embryos (Fig. 1K). Thus, the absence of $\beta$-gal expression in exd $d^{\text {mat }^{-}, \text {zyg }^{-}}$embryos is unlikely to only be due to the regulation of Scr by exd.

Although the above results show a genetic requirement for Scr and exd for fkh[250] activation, they do not address whether these homeodomain proteins act directly on this enhancer. To examine whether a Scr/Exd heterodimer directly binds this element in vivo, we generated point mutations in the Hox/Exd-binding site. As with the wild-type element, the mutant oligonucleotides were tested for activity in vivo by cloning four copies upstream of a minimal promoter driving lacZ. Within the Hox/Exd-binding site, the 5' half, AGAT, resembles an Exd half-site, and the $3^{\prime}$ half, TAATCG, resembles the Hox half-site. On the basis of the Hox/Exd crystal structures (Passner et al. 1999; Piper et al. 1999), we mutated basepairs that make critical contacts with either Exd or Hox proteins. These mutations eliminate binding in vitro (see below). When the the Exd half-site was mutated to AGGT (Fig. 1A,L), or when the Hox half-site was mutated to TGGTCG (Fig. 1A,M), $\beta$-gal was no longer detected in PS 2. These results demonstrate that the Hox/Exd-binding site within fkh[250] is necessary for its activity in PS 2, and suggest that activation is mediated, at least in part, by an Scr/Exd heterodimer bound to this element.

\section{The amino-terminal arm of the Scr homeodomain is required for activation of fkh[250]}

To further test the in vivo specificity of $f k h[250]-1 a c Z$ for $S c r$, we investigated how this reporter gene responds to ectopic expression of other Antp-class Hox genes. Whereas in wild-type embryos fkh[250]-lacZ expression is restricted to the ventral side of PS 2 (Fig. 2B), ectopic Scr driven by a HS:Scr transgene expanded expression of this element anteriorly as well as posteriorly (Fig. 2C). This activation is similar to that of the $f k h$ gene in response to ectopic Scr (Panzer et al. 1992). In contrast with Scr, ectopic expression of Antp, which differs in only four amino acids within the homeodomain, or $U b x$, which differs in only nine amino acids within the homeodomain, failed to expand $f k h[250]-1 a c Z$ expression when ectopically expressed (Fig. 2D,E). Thus, the fkh[250] element is specifically activated by $S c r$, but not by highly related Hox proteins.

Within their homeodomains, Scr and Antp differ in four amino acids, all of which are located in their amino- 
A
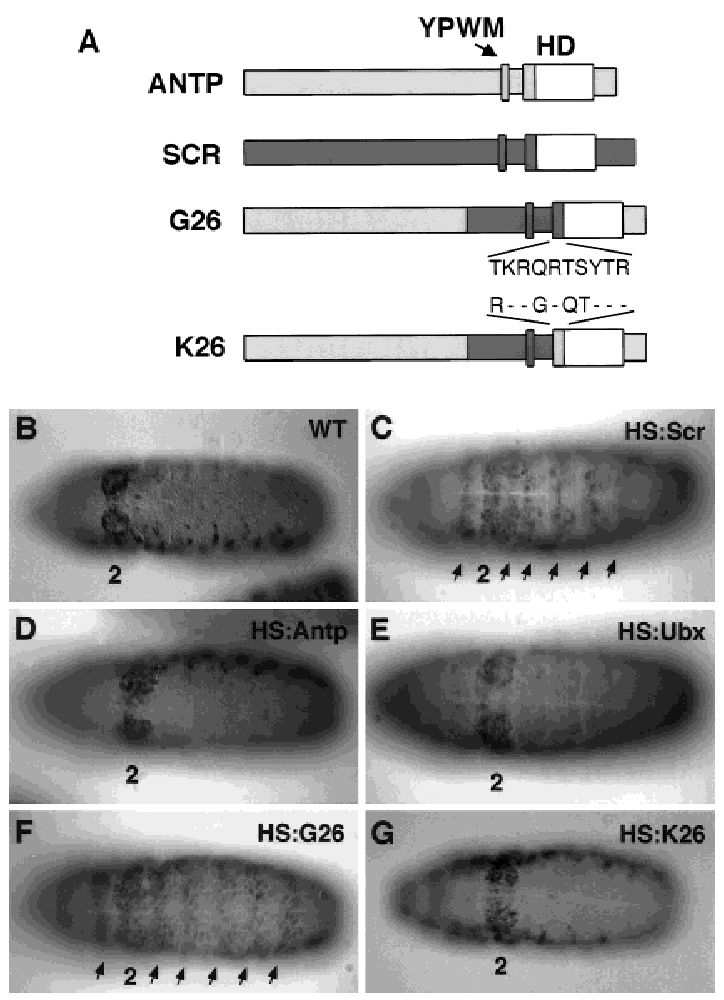

Figure 2. Effects of ectopic Hox expression on the fkh[250] element. (A) Structure of Antp, Scr, and chimeric proteins, G26 and K26. The YPWM and homeodomain are shown as small and large boxes, respectively. Antp-specific sequences are shown in light gray, Scr-specific sequences are shown in dark gray, and homeodomain sequences that are identical in both proteins are shown in white. The only amino acid differences between G26 and $\mathrm{K} 26$ are in the amino-terminal arm of the homeodomain, as indicated. $(B-G)$ All embryos are ventral views histochemically stained for $\beta$-gal (black). Wild-type $f k h[250]-l a c Z$ expression is limited to PS $2(B)$; but on ectopic Scr expression, $\beta$-gal staining is expanded anteriorly and posteriorly ( $C$, arrows). Ectopic Antp $(D)$ or $\mathrm{Ubx}(E)$ do not activate this element. Ectopic expression of G26 expands $\beta$-gal ( $F$, arrows), whereas ectopic K26 does not $(G)$.

terminal arms (Fig. 2A). This four-amino-acid difference is crucial for these proteins to specify distinct embryonic and adult structures (Gibson et al. 1990; FurukuboTokunaga et al. 1993; Zeng et al. 1993). Scr-Antp chimeras containing the amino-terminal arm from Antp generated structures normally dictated by Antp, whereas other chimeras containing the amino-terminal arm from Scr behaved as Scr (Furukubo-Tokunaga et al. 1993; Zeng et al. 1993). By use of such chimeras, we tested if the activation of fkh[250] also exhibited specificity for the Scr amino-terminal arm. Whereas HS:G26, a chimera with the Scr amino-terminal arm (Fig. 2A), expanded $\beta$-gal expression (Fig. 2F), HS:K26, which differs from G26 in only four amino-terminal arm amino acids (Fig. $2 \mathrm{~A})$, failed to expand $\beta$-gal expression (Fig. 2G). These experiments demonstrate that the Scr amino-terminal arm is critical for the specific activation of fkh[250] in vivo.

\section{fkh[250] prefers to bind Scr/Exd heterodimers in vitro}

If Exd confers specificity to Hox proteins, the fkh[250] element, which is specifically turned on by Scr in vivo, should specifically bind Scr/Exd heterodimers in vitro. We tested this prediction by performing electrophoretic mobility shift assays (EMSAs) on the fkh[250] oligo with four Hox proteins, Scr, Antp, Ubx, and Abd-A, in the absence and presence of Exd. Exd did not bind to this oligo on its own (Fig. 3A, lane 2) and all four Hox proteins bound poorly as monomers (Fig. 3A, lanes $3,4,7,8,11,12,15,16)$. When Exd was combined with individual Hox proteins, only Scr made a robust and stable DNA-bound heterodimer with Exd (Fig. 3A, lanes 5,6). The other Hox proteins were apparently stimulated to bind fkh[250] as monomers in the presence of Exd, but did not generate stable heterodimers in this assay (Fig. 3A, lanes 9,10,13,14,17,18).

To confirm that Scr/Exd was binding to the putative Hox/Exd-binding site in fkh[250], we performed EMSAs with oligos that had point mutations in either the Scr or Exd half-sites (Fig. 1A). Mutations in either half-site prevented Scr/Exd heterodimer formation (Fig. 3B). As expected, an oligo with a mutation in the Exd half-site, fkh $[250]^{\text {exd }}$, was able to weakly bind to Scr monomers, as did the wild-type oligo (Fig. 3B, lane 2-6). An oligo with a mutated Scr half-site, fkh[250] ${ }^{\mathrm{Scr}}$, abolished monomer and heterodimer binding (Fig. 3B, lane 7-12). These results suggest that Scr/Exd heterodimers are binding to $\mathrm{fkh}[250]$ in a manner that is similar to Hox/Exd heterodimers characterized previously (Passner et al. 1999; Piper et al. 1999). Moreover, they demonstrate that the binding site present in fkh[250] prefers Scr/Exd heterodimers over other Hox/Exd heterodimers.

One explanation for the inability of Antp, Ubx, and Abd-A to efficiently form heterodimers with Exd on $\mathrm{fkh}[250]$ is that these proteins cannot cooperatively bind with Exd to any sequence. This seemed unlikely, however, because the mammalian Antp class Hox proteins form heterodimers with the Exd homolog Pbxl, and the preferred binding site is the consensus sequence, TGATTTATGG (Knoepfler and Kamps 1995; Lu et al. 1995; Pöpperl et al. 1995; Chang et al. 1996; Neuteboom and Murre 1997). Nevertheless, to rule out this possibility, we tested the ability of these four Hox proteins to cooperatively bind with Exd to a consensus Hox/Exdbinding site. In our experiments, we used an oligo called $\mathrm{fkh}\left[250^{\mathrm{con}}\right]$ in which two base pairs in the fkh[250]-binding site were changed so that it resembled the $\mathrm{Hox} / \mathrm{Pbx}$ consensus site (Fig. 1A). As with fkh[250], Exd did not bind to fkh $\left[250^{\mathrm{con}}\right]$ on its own (Fig. 3C, lane 2), and these HOX proteins bound only weakly in the absence of Exd (Fig. 3C, lanes 3,4,7,8,11,12,15,16). In the presence of Exd, robust complex formation was observed with all four of these Antp class Hox proteins (Fig. 3C, lanes $5,6,9,10,13,14,17,18)$. The concentrations of the Hox and Exd proteins used in this experiment were identical to those used in the experiment shown in Figure 3A. We conclude that all four of these Hox proteins are capable of cooperatively binding with Exd on a consensus Hox/ 
A

B

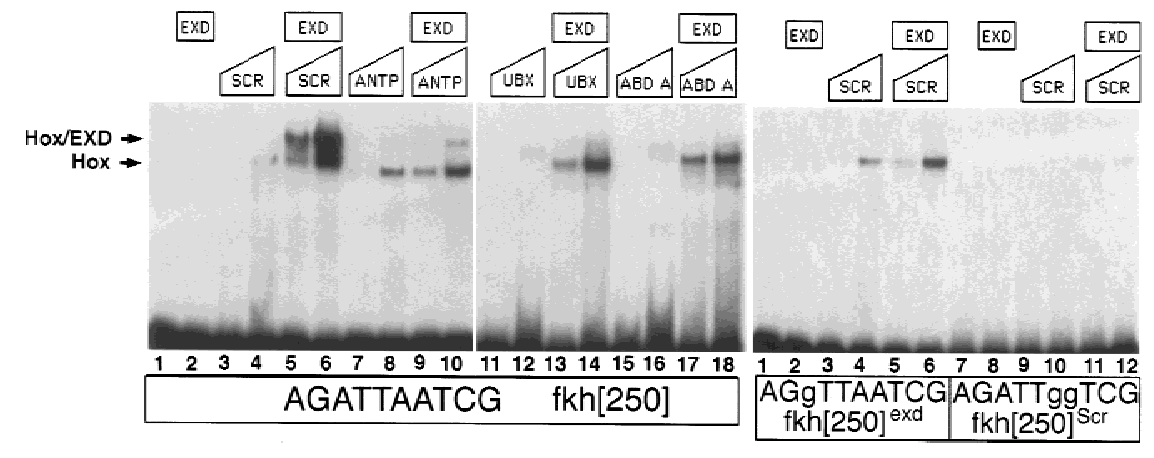

Figure 3. Hox/Exd-binding preferences of $\mathrm{fkh}[250]$ and fkh[250 $\left.{ }^{\mathrm{con}}\right]$. (A) EMSA using the fkh[250] oligo with Hox and Exd proteins as indicated. There is a preference for binding Scr/Exd heterodimers over Antp/ Exd, Ubx/Exd, and Abd-A/Exd heterodimers. $(B)$ EMSA with the fkh $[250]^{\text {exd }}$ or $\mathrm{fkh}[250]^{\mathrm{Scr}}$ oligos with Scr and Exd as indicated. Mutation of the Exd half-site (fkh[250] $\left.]^{\text {exd }}\right)$ or the Scr half-site (fkh[250] $]^{\text {Scr }}$ ) abolished Scr/Exd complex formation. $(C)$ EMSA with the fkh $\left[250^{\text {con }}\right]$ oligo with Hox and Exd proteins as indicated. All four heterodimers (Scr/Exd, Antp/Exd, Ubx/Exd, Abd-A/Exd) bound strongly to the $\mathrm{fkh}\left[250^{\mathrm{con}}\right]$ oligonucleotide. The concentrations of all proteins used in $C$ were identical to those in $A$, and these EMSAs were carried out at the same time.

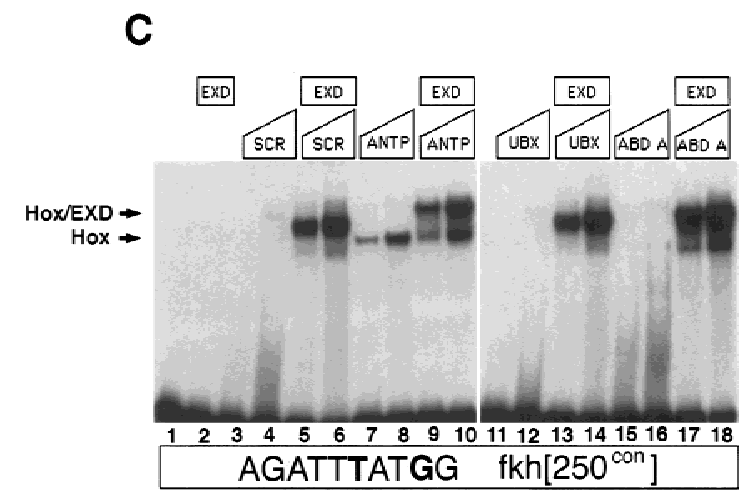

Exd-binding site, as is the case with their mammalian homologs.

These experiments demonstrate that although all four of these Hox proteins have the ability to form heterodimers on a consensus Hox/Exd-binding site, there exist binding sites that show a preference for one Hox/ Exd heterodimer over another. The binding site in $\mathrm{fkh}[250]$ prefers to bind Scr/Exd heterodimers in vitro, reflecting the specificity of this enhancer in vivo.

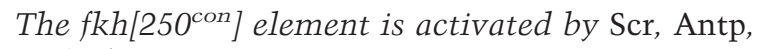
and Ubx in vivo

If Exd is a specificity cofactor for the Antp class Hox proteins, one prediction is that the fkh $\left[250^{\text {con }}\right]$ element, which is able to bind several different Hox/Exd heterodimers in vitro, might be activated by these Hox proteins in vivo. To test this possibility, we constructed a reporter gene with four copies of the fkh $\left[250^{\text {con }}\right]$ element upstream of a minimal promoter driving lac $Z$ and tested its activity in vivo. Whereas expression of fkh $\left[250^{\text {con }}\right]-$ lacZ was primarily limited to PS 2 (Fig. 4A), expression of $f k h\left[250^{c o n}\right]-l a c Z$ was observed from PS 2 through PS 6 (Fig. 4B-F). These parasegments are where Scr, Antp, and Ubx are most highly expressed. Double staining with Antp (Fig. 4C,D) or Engrailed (En) (Fig. $4 \mathrm{E}, \mathrm{F})$ confirmed that $f \mathrm{kh}\left[250^{\mathrm{con}}\right]-\mathrm{lac} Z$ was expressed in PS 2 through 6. Expression was also observed at the posterior of the embryo (PS 14 and 15), but not in PS 7 to PS 13 in which $a b d-A$ is expressed (Fig. 4E,F). Also, as with the fkh[250] element, weak expression was observed in lateral regions of $f k h\left[250^{\text {con }}\right]-$ lac $Z$ embryos.

The expression pattern driven by the fkh $\left[250^{\text {con }}\right]$ ele-

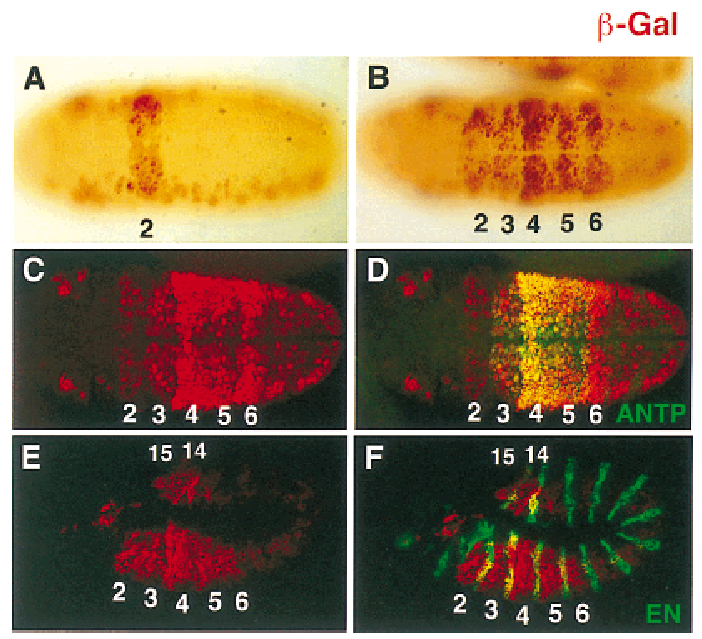

Figure 4. Different expression patterns dictated by $f k h[250]-$ $l a c Z$ and $f k h\left[250^{c o n}\right]-l a c Z$ in vivo. $(A, B)$ Histochemically stained $f k h[250]-1 a c Z(A)$ and $f k h\left[250^{\text {con }}\right]-l a c Z(B)$ embryos stained for $\beta$-gal (brown). Expression of the fkh[250]-lacZ element is confined to PS $2(A)$ and expression of $f k h\left[250^{\text {con }}\right]-l a c Z$ is observed from PS 2 through PS $6(B)$. $(C-F)$ Fluorescent double labeling of $f k h\left[250^{\text {con }}\right]-l a c Z$ embyros for $\beta$-gal (red) and Antp (green) $(C, D)$, or En (green) $(E, F)$ localizes the $f k h\left[250^{\text {con }}\right]-l a c Z$ expression domain from PS 2 to PS 6. Expression of $f k h\left[250^{c o n}\right]-$ $l a c Z$ in PS 14 and PS 15 can be seen in $(E$ and $F)$. 
ment suggested that it was activated by $S c r, A n t p$, and $U b x$. To confirm that this element is being activated by these trunk Hox proteins and Exd, we analyzed $\beta$-gal expression in various mutant backgrounds. In ex $d^{\text {mat }^{-}, \text {zyg }^{-}}$embryos, $\beta$-gal staining was eliminated in all parasegments (Fig. 5B). In $S c r^{-} A n t p^{-}$double-mutant embryos, $\beta$-gal was no longer observed in PS 2 to PS 5, but staining in PS 6 and in the most posterior segments remained (Fig. 5C; data not shown). In $\mathrm{Scr}^{-} A n t p^{-} U b x^{-}$ triple-mutant embryos, expression of $\beta$-gal was not observed in PS 2 to PS 6, but staining remained in the very posterior of the embryo (Fig. 5D; data not shown). Moreover, ectopic expression of Antp (Fig. 5E) or Ubx (Fig. 5F) in the patched domain with the Gal4-UAS system (Brand and Perrimon 1993) activated fkh[250 con $]-1 a c Z$ ectopically. Thus, although fkh[250] is specifically activated by $\mathrm{Scr}, \mathrm{fkh}\left[250^{\mathrm{con}}\right]$ is activated by Scr, Antp, and Ubx.

To confirm that the Hox/Exd-binding site in $\mathrm{fkh}\left[250^{\mathrm{con}}\right]$ is required for its activation in vivo, we introduced point mutations that disrupt each half-site (Fig.

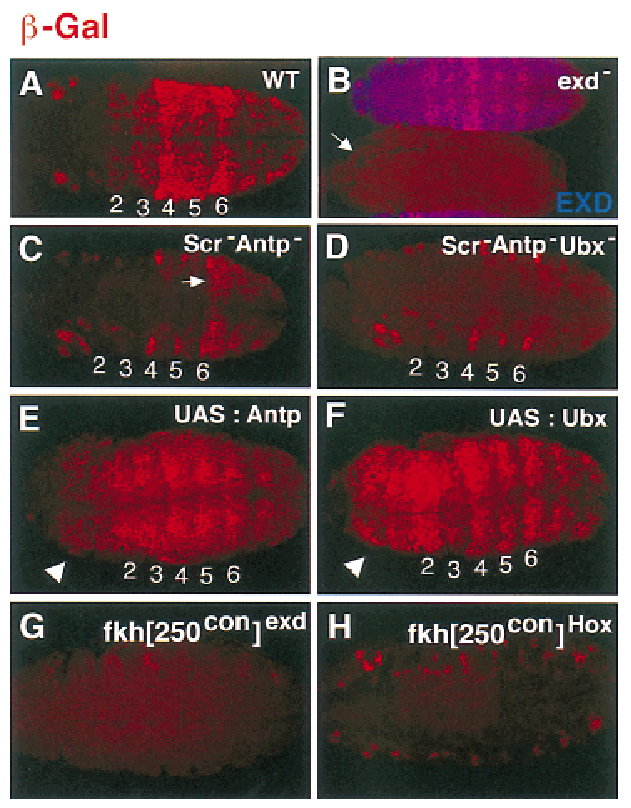

Figure 5. $f k h\left[250^{c o n}\right]-1 a c Z$ expression requires $S c r, A n t p, U b x$, and exd and both halves of the Hox/Exd-binding site. $(A-F)$ fkh $\left[250^{\text {con }}\right]-l a c Z$ expression in $(A)$ wild type, $(B)$ exd $^{\text {mat }^{-}, \text {zyg }^{-}},(C)$ $S c r^{-} A n t p^{-},(D) S_{C r}^{-} A n t p^{-} U b x^{-},(E)$ ectopic Antp, and $(F)$ ectopic Ubx backgrounds. All embryos were stained for $\beta$-gal (red). In $B$ the embryos were costained for Exd to identify the ex $d^{\text {mat }^{-}, \text {zyg }^{-}}$embryos (arrow); the embryo that stains in $B$ is paternally rescued for exd $\left(\mathrm{mat}^{-}, \mathrm{zyg}^{+}\right)$. In $\mathrm{Scr}^{-} A n t p^{-}$embryos $(C)$, expression in PS 2 to PS 5 is absent but remains in PS 6 (arrow). In $\mathrm{Scr}^{-} A n t p^{-} U b x^{-}$embryos (D), expression is absent in PS 2 to PS 6 . The arrowheads in $E$ and $F$ point to ectopic $\beta$-gal expression in the head induced by Antp or Ubx. $(G, H)$ $f k h\left[250^{c o n}\right]^{e x d}-l a c Z(G)$ or $f k h\left[250^{c o n}\right]^{S c r}-l a c Z(H)$ embryos stained for $\beta$-gal (red). Mutation of the Exd half-site $(G)$, or the Hox half-site $(F)$ abolishes $f k h\left[250^{\text {con }}\right]-l a c Z$ expression in PS 2 to PS 6. See Fig. 1A for the sequences of the mutant-binding sites.
$1 \mathrm{~A}$, and generated the corresponding reporter genes. $\mathrm{Mu}-$ tation of the Exd half-site, AGAT, into AGGT, abolished most $\beta$-gal expression, except for expression in PS 14 to PS 15, which remained (Fig. 5G; data not shown). Mutation of the Hox half-site, TTATGG, into TTGTGG, abolished nearly all $\beta$-gal expression, including expression in PS 14 to PS 15 (Fig. 5H; data not shown). These data are consistent with the idea that Scr, Antp, and Ubx form heterodimers with Exd on this DNA in vivo. Further, these data suggest that the factor activating fkh $\left[250^{\text {con }}\right]$ in PS 14 to PS 15 does not require the Exd half-site and therefore is probably not forming heterodimers with Exd. Although this domain overlaps with expression of the Hox gene $A b d-B, A b d-B^{-}$mutant embryos still express this reporter gene (data not shown). Another possible activator is the homeodomain protein Caudal, which is also expressed in this region of the embryo (Macdonald and Struhl 1986; Mlodzik and Gehring 1987). Consistent with this possibility, Caudal is able to activate transcription by binding to the sequence TTATGG (Dearolf et al. 1989), which is the sequence of the Hox half-site in $\mathrm{fkh}\left[250^{\mathrm{con}}\right]$.

Hox genes are expressed not only during embryogenesis, but also during the larval stages in imaginal discs, which are the precursors of the adult structures. The leg imaginal discs from the first thoracic segment (T1) express $S c r$, the leg and wing discs from T2 express Antp, and the leg and haltere discs from T3 express $U b x$ (White and Wilcox 1985; Condie et al. 1991; Pattatucci and Kaufman 1991). Strikingly, both the fkh[250] and $\mathrm{fkh}\left[250^{\mathrm{con}}\right]$ elements drive $\beta$-gal expression in imaginal discs, and this expression correlates with the Hox proteins these elements bind in vitro. fkh[250]-lacZ expression was observed in T1 leg discs, but not in the other thoracic discs (Fig. 6A). In contrast, fkh[250 $\left.{ }^{\text {con }}\right]-1 a c Z$ expression was observed in all leg discs, wing, and haltere discs (Fig. 6E-H). For both elements, the expression of $1 a c Z$ in discs was in a ring that, in the leg, approximately corresponds to the future trochanter, a region in which Exd is nuclear and functional (Abu-Shaar and Mann 1998). The ring-like expression pattern suggests that other regulators act on these elements and limit their activities along the proximo-distal axis. For both $f k h[250]-1 a c Z$ and $f k h\left[250^{c o n}\right]-l a c Z$ expression was also observed in antennal discs, in which no known Hox gene is active, but where Exd is nuclear (data not shown; Rieckhof et al. 1997; Casares and Mann 1998).

These results support a model in which Exd has the ability to act as a cofactor for the Hox proteins Scr, Antp, and Ubx. Moreover, as fkh[250] and fkh[250 $\left.{ }^{\text {con }}\right]$ illustrate, different Hox/Exd heterodimers have different DNA-binding preferences that correlate with the activities of these enhancers in vivo.

abd-A represses fkh $\left[250^{\text {con }}\right]-1 \mathrm{acZ}$

Although Abd-A/Exd heterodimers bind fkh $\left[250^{\text {con }}\right]$ in vitro, strong $f k h\left[250^{\text {con }}\right]-l a c Z$ expression was not detected in the abdominal segments in which $a b d-A$ is expressed (Fig. 7A,B). Because the abdominal segments 


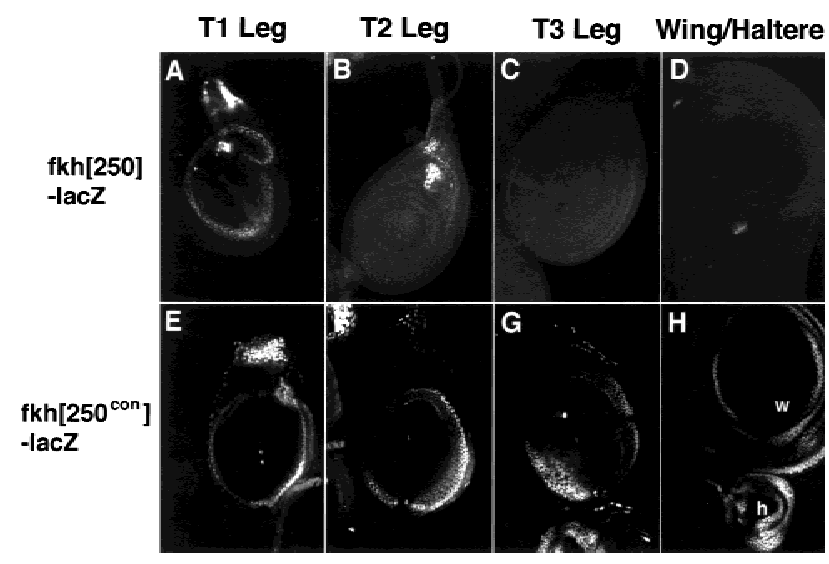

Figure 6. Expression of $f k h[250]-1 a c Z$ and $f k h\left[250^{c o n}\right]-1 a c Z$ in imaginal discs. $(A-D)$ Fluorescent images of imaginal discs from $f k h[250]-1 a c Z$ larvae stained for $\beta$-gal (white). fkh[250]-lac $Z$ is expressed in the T1 leg disc $(A)$, but not in the T2 $(B)$, or T3 $(C)$ leg discs, and not in the wing $(D)$ or haltere (not shown) discs. The cells staining in $B$ are mesodermal cells associated with the T2 leg disc that express Scr (Percival-Smith et al. 1998). (E-H) Fluorescent images of imaginal discs from $\mathrm{fkh}\left[250^{\mathrm{con}}\right]-$ lac $Z$ larvae stained for $\beta$-gal (white). $f k h\left[250^{\text {con }}\right]-l a c Z$ is expressed in all thoracic discs, including T1 $(E)$, T2 $(F)$, and T3 $(G)$ leg discs, wing $(\mathrm{w})$ and haltere $(\mathrm{h}) \operatorname{discs}(H)$.

have lower levels of nuclear Exd than the thoracic segments (Azpiazu and Morata 1998), we considered the possibility that limiting amounts of nuclear Exd could account for the lack of $f k h\left[250^{c o n}\right]-l a c Z$ expression in these segments. We tested this idea by artificially generating high levels of nuclear Exd in the abdominal segments by ectopically expressing the gene $h t h$, which is necessary and sufficient to import Exd into nuclei (Rieckhof et al. 1997; Pai et al. 1998; Abu-Shaar et al. 1999). Because exd transcription is also down-regulated in the abdomen (Rauskolb et al. 1993; Azpiazu and Morata 1998), we ectopically expressed both Exd and Hth using the patched-Gal4 driver. As a result, these embryos had Hth and nuclear Exd levels that were at least three times higher than wild type (Fig. 7D,F). However, $f k h\left[250^{c o n}\right]-l a c Z$ expression in these embryos was similar to its expression in wild type (Fig. 7A,E). Thus, the lack of $\mathrm{fkh}\left[250^{\mathrm{con}}\right]$ expression in the abdomen is unlikely to be due to limiting amounts of nuclear Exd.

In $a b d-A^{-} A b d-B^{-}$embryos, $\mathrm{fkh}\left[250^{\mathrm{con}}\right]$ expression is derepressed in the abdominal segments, consistent with the idea that Abd-A is a repressor of this element (Fig. 7C). The pattern and level of $\beta$-gal in the abdominal segments of these embryos are similar to the level in PS 6, in which UBX is expressed. These data are consistent with $a b d-A$ acting either directly or indirectly to repress this reporter gene; it is possible, for example, that the derepression of $f k h\left[250^{c o n}\right]-l a c Z$ in $a b d-A^{-} A b d-B^{-}$embryos is an indirect effect of derepressing $U b x$, which is also repressed by $a b d-A$ (Struhl and White 1985). However, these results raise the possibility that Abd-A directly represses the $\mathrm{fkh}\left[250^{\mathrm{con}}\right]$ enhancer, perhaps as an Abd-A/Exd heterodimer.
Loss of nuclear Exd limits Scr's ability to activate fkh and fkh[250]-lacZ to early stages of embryogenesis

$f k h$ expression and salivary gland formation is genetically dependent on $S c r$ and, once activated, fkh remains on throughout salivary gland development (Panzer et al. 1992). Scr expression is not maintained, however, in salivary glands during the later stages of embryogenesis and, conversely, the cells that do express Scr in older embryos do not express fkh (Fig. 8A,B). Thus, Scr's ability to activate $f k h$ is temporally regulated, raising the question of how this change in Scr's activity occurs.

It has been suggested that the activity of the Hox proteins can be controlled by regulating the nuclear localization of Exd (Mann and Abu-Shaar 1996; Aspland and White 1997; Rieckhof et al. 1997). We tested whether this aspect of Exd regulation could account for modulating the activity of $S c r$ during development. Double staining of wild-type embryos with anti-Scr and anti-Exd antibody showed that in germ-band elongating embryos (stages 9 and 10) Scr and Exd are colocalized in PS 2 nuclei (Fig. 1B,C). At these stages, Scr and $f k h-l a c Z$ are also expressed in the same cells (Fig. 1D,E), as is

\section{$\beta$-Gal}
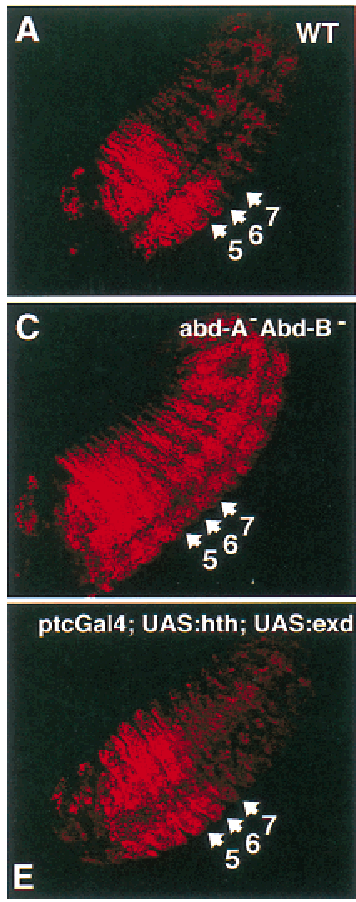
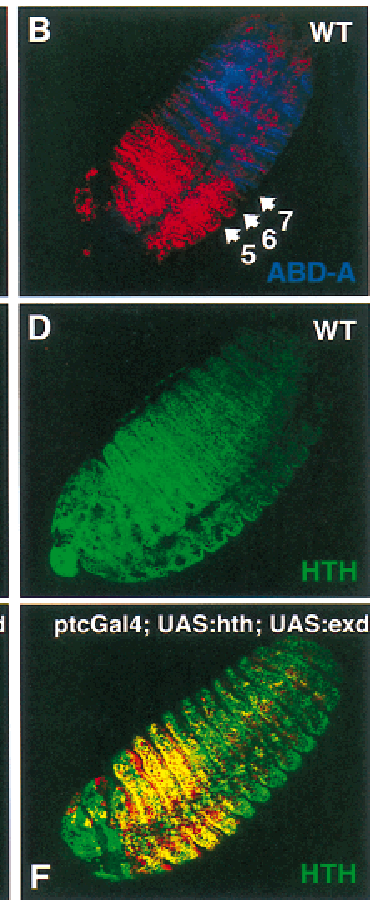

Figure 7. $a b d-A$ represses $f k h\left[250^{c o n}\right]-l a c Z$ in abdominal segments. $(A, B)$ Fluorescent images of a wild-type $f k h\left[250^{\text {con }}\right]-l a c Z$ embryo double stained for Abd-A (blue) and $\beta$-gal (red). $\beta$-Gal expression is weak in the $a b d-A$ domain. $(C)$ Fluorescent image of a $f k h\left[250^{c o n}\right]-l a c Z$; $a b d-A^{-} A b d-B^{-}$embryo stained for $\beta$-gal (red). Derepression of $\beta$-gal in the $a b d$ - $A$ domain is observed. (D) Fluorescent image of a wild-type embryo stained for Hth (green), which is weak in the $a b d-A$ domain. $(E, F)$ Fluorescent image of a ptc-Gal4; UAS:hth; UAS:exd embryo stained for Hth (green) and $\beta$-gal (red). Despite ectopic Hth and nuclear Exd (not shown), fkh[250 $\left.{ }^{\text {con }}\right]-l a c Z$ is still repressed in the $a b d-A$ domain. 

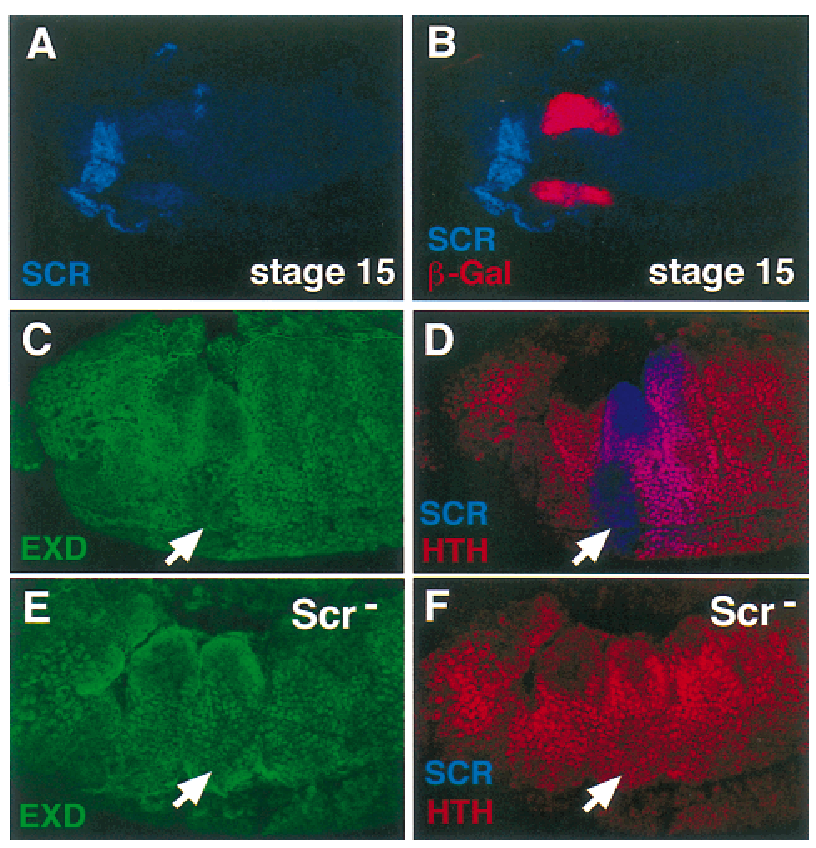

Figure 8. Scr represses $h t h$, resulting in the cytoplasmic localization of Exd in PS 2 of stage 12 and older embryos. $(A, B)$ Lateral view of a stage $15 \mathrm{fkh}-\mathrm{lacZ}$ embryo doubly stained for $\beta$-gal (red) and Scr (blue). At this stage, the expression of $f k h-$ lacZ is limited to the salivary glands and shows no overlap with Scr. $(C, D)$ In stage 12 embryos, PS 2 cells express Scr (blue), have cytoplasmic Exd (green) and no Hth (red) (arrows). (E,F) In Scr stage 12 embryos, Exd is nuclear $(E)$, and Hth is expressed in this region of the embryo (arrows).

fkh[250]-lacZ (Fig. 1F,G). However, by stage 12, fkh and $f k h[250]-1 a c Z$-expressing cells start invaginating to form the salivary gland (Panzer et al. 1992), and Scr expression is turned off in these cells (Fig. 8A,B). Scr expression persists in other regions of PS 2 that do not express $f k h$, but at this stage, Exd is no longer detected in most PS 2 nuclei (Fig. 8C). hth, which is required for Exd's nuclear localization, is also absent from PS 2 at later stages of embryogenesis (Fig. 8G) (Rieckhof et al. 1997). Because $f k h$ and $f k h[250]-1 a c Z$ require Scr and Exd for expression, the absence of nuclear Exd in the Scr-positive nuclei of stage 11 and older embryos might account for Scr's inability to activate $f k h$ later in embryogenesis.

The above observations raise the question of what controls the shift of Exd from the nucleus to the cytoplasm in PS 2. One possibility is that Scr alone causes this shift by repressing $h t h$. To test this hypothesis, we examined Hth and Exd in $\mathrm{Scr}^{-}$mutant embryos. In wild-type stage12 embryos, when the germ band is being retracted, Hth expression is absent and Exd cannot be detected in ventral PS 2 nuclei in which Scr is expressed (Fig. 8C,D). In stage $12 \mathrm{Scr}^{-}$embryos Hth and nuclear Exd were observed throughout this region of the embryo (Fig. 8E,F). Therefore, Scr represses hth and, consequently, the nuclear accumulation of its own cofactor, Exd, thereby modulating its ability to regulate target genes in a temporally dynamic manner.
If the lack of nuclear Exd was the only reason for Scr's inability to activate $\mathrm{fkh}[250]$ later in embryogenesis, then forcing the nuclear localization of Exd in these Screxpressing cells should activate $\mathrm{fkh}$ [250]. However, this appears not to be the case: Ectopic expression of Hth or Hth plus Exd did not ectopically activate fkh[250]-lacZ, even in Scr-expressing cells (data not shown). We conclude that in addition to the lack of nuclear Exd, there are additional mechanisms that make Scr-positive cells not competent to activate $\mathrm{fkh}[250]$ in older embryos.

\section{Discussion}

\section{Exd confers specificity to highly similar Hox proteins} in vivo

As outlined in the Introduction, Exd has been suggested to perform two different functions as a Hox cofactor: The first model suggests that Exd enhances the DNA-binding specificity of the Hox proteins in vivo, whereas the second model suggests that Exd changes the regulatory properties of the Hox proteins. For the reasons discussed below, the data presented here provide strong support for the first model.

In these experiments we characterized two Hox/Exdbinding sites; the first, present in $\mathrm{fkh}[250]$, is derived from an enhancer from the $f k h$ gene, a natural target of the Hox gene Scr. In vitro, fkh[250] shows a preference for binding Scr/Exd heterodimers over other Hox/Exd heterodimers. In the absence of a functional Exd halfsite, the Hox half-site in fkh[250] weakly binds several Hox proteins, but when the Exd half-site is functional, one of these Hox proteins (Scr) binds better than the others; thus, Exd selectively enhances the binding of one Hox protein over the others. Another Hox/Exd-binding site, present in $\mathrm{fkh}\left[250^{\text {con }}\right]$, binds at least four different Hox/Exd heterodimers. In this case, Exd enhances the affinity of all four Hox proteins to this sequence. Outside of two basepair differences in the Hox/Exd-binding site, $\mathrm{fkh}[250]$ and $\mathrm{fkh}\left[250^{\mathrm{con}}\right]$ are identical. Yet in vivo, they generate very different patterns of expression: $\mathrm{fkh}[250]$ generates an Scr- and exd-dependent pattern of expression in PS 2, whereas fkh $\left[250^{\text {con }}\right]$ generates a more general Hox- and exd-dependent pattern of expression. Taken together, these results strongly suggest that Exd enhances the functional specificity of the Hox proteins, even among those that have very similar DNA-binding specificities as monomers. These results also suggest that subtle differences between Hox/Exd-binding sites are critical for distinguishing between different Hox/Exd heterodimers, both in vitro and in vivo.

Our results do not rule out that there are other sequences in $\mathrm{fkh}[250]$ that contribute to its specific spatial and temporal activation in vivo. The fact that $\mathrm{fkh}[250]$ is activated in a subset of cells that have both Scr and nuclear Exd suggest that other regulators also act on this enhancer in vivo. Its limited activation along the proximo-distal axis of imaginal discs also implies the existence of additional regulators. Nevertheless, the ability to alter the Hox responsiveness of this enhancer by 
only changing basepairs within the Hox/Exd-binding site suggests that different Hox/Exd-binding sites are sufficient to direct different Hox-dependent patterns of expression in vivo.

Although the Hox/Exd-binding site present in fkh[250] shows a preference for Scr/Exd, we do not suggest that all Hox/Exd-binding sites will show a preference for a particular Hox protein. There may be many functional Hox/Exd-binding sites in the genome that do not discriminate between different Hox/Exd heterodimers. In fact, on the basis of our limited knowledge of Hox target genes, Hox proteins, especially those expressed in the trunk and abdominal segments, probably activate many of the same target genes (Graba et al. 1997). These target genes may utilize-binding sites that are similar to the Hox/Exd site in fkh[250 $\left.{ }^{\text {con }}\right]$, which can be activated effectively by several different Hox/Exd heterodimers in vivo.

$f k h$, however, is an example of a Hox target gene that is specifically activated by Scr, but not by other highly related Hox genes. The specificity of this regulation is critical for limiting salivary gland morphogenesis to cells derived from PS 2 . We suggest that the specificity exhibited by the Scr/Exd-binding site in fkh[250] may be critical to this regulation. Given the limited number of characterized Hox target enhancers, we cannot predict the frequency of specific versus nonspecific Hox/Exd-binding sites in the genome. But it is clear that specific Hox/ Exd-binding sites do exist, and probably play an important role in mediating Hox functions.

There are other examples of Hox target genes that are known to be specifically activated by only one Hox protein in combination with Exd. One example is the Hox gene $1 a b$, which is positively autoregulated by a Lab/Exd heterodimer bound to a single Lab/Exd-binding site (Grieder et al. 1997). This binding site, like the one described here for Scr/Exd, strongly prefers Lab/Exd heterodimers over other Hox/Exd heterodimers. Moreover, the Lab/Exd-binding site differs in sequence from the Scr/Exd or consensus binding sites, again suggesting that subtly different Hox/Exd-binding sites direct distinct Hox-dependent outputs in vivo. A second example is the $d p p$ gene, which requires $U b x$ and exd for its activation in PS 7 of the visceral mesoderm (Chan et al. 1994). However, in the $d p p$ enhancer that directs this expression, there are no sequences that fit the consensus Hox/Exdbinding site, suggesting that these proteins may bind to this enhancer differently from how Scr/Exd or Lab/Exd recognize their-binding sites, respectively. Finally, the $D f d$ autoregulatory enhancer also requires exd for its activation (Pinsonneault et al. 1997). In this enhancer, Hox/Exd-binding sites have been identified that, as multimerized 20-bp oligonucleotides, can generate a $D f d$ pattern of expression in vivo (Chan et al. 1997). In addition, Dfd and Exd also bind to other regions of this enhancer that do not contain consensus Hox/Exd-binding sites (Pinsonneault et al. 1997).

From this survey, there are several examples of specific Hox/Exd-binding sites that, like the Scr/Exd-binding site described here, generate specific Hox-dependent outputs in vivo. However, there may be additional ways in which Hox and Exd proteins can effectively interact on target enhancers. Furthermore, on the basis of our characterization of $\mathrm{fkh}\left[250^{\mathrm{con}}\right]$, we suggest that there exist Hox/Exd-binding sites that do not discriminate between different Hox/Exd heterodimers. In principle, these-binding sites could be used in target gene enhancers that are activated by multiple Hox proteins.

\section{Importance of the Hox amino-terminal arm in Hox/Exd heterodimers}

The characterization of chimeras generated between closely related Hox proteins such as Scr and Antp (Gibson et al. 1990; Furukubo-Tokunaga et al. 1993; Zeng et al. 1993), Antp and Ubx (Mann and Hogness 1990; Chan and Mann 1993), and Dfd and Ubx (Kuziora and McGinnis 1989; Lin and McGinnis 1992) has consistantly come to the conclusion that the homeodomains of these proteins are important for their specific in vivo functions. This was surprising because the homeodomains are highly similar among the Antp class of Hox proteins; in fact, some of these homeodomains exhibit nearly identical DNA-binding properties in vitro (Ekker et al. 1994). Moreover, differences within the amino-terminal arms of these homeodomains are necessary and in some cases sufficient for distinguishing between their functions in vivo (Furukubo-Tokunaga et al. 1993; Zeng et al. 1993; Phelan et al. 1994). We have shown here that the significance of the Hox amino-terminal arm can be extended to the activation of the fkh[250] element in vivo. However, we have not demonstrated that differences between the amino-terminal arms of Scr and Antp are sufficient to account for their different in vitro DNA-binding properties in the presence of Exd; from our experiments it is possible that other regions of these proteins contribute to these differences. Nevertheless, the amino-terminal arm of Scr is likely to be, at least in part, responsible for selecting specific Hox/Exd-binding sites in vivo.

There are two crystal structures of Hox/Exd (or Pbx) heterodimers bound to DNA in which the Hox aminoterminal arm can be examined (Passner et al. 1999; Piper et al. 1999). As expected from the in vitro and in vivo data, the Hox amino-terminal arm is located in the center of the complex, in the minor groove, close to basepairs 5 and 6 of the Hox/Exd-binding site. It is these basepairs that are known to influence Hox binding /Chan and Mann 1996; Chang et al. 1996; Shen et al. 1996; Chan et al. 1997; Phelan and Featherstone 1997; Wilson and Desplan 1999). However, despite the importance of the Hox amino-terminal arm in specificity, these amino acids are not making any specific interactions with the DNA. In fact, the first three amino acids of the Hox amino-terminal arms are disorded in both structures, as they are in the crystal structures of homeodomain monomers bound to DNA (Kissinger et al. 1990; Wolberger et al. 1991; Hirsch and Aggarwal 1995; Fraenkel and Pabo 1998). How might we rationalize the importance of the Hox amino-terminal arm with the lack of specific interactions seen in the Hox/Exd crystal structures? One pos- 
sibility stems from the fact that the Hox/Exd-binding sites present in both crystal structures are consensus sites, similar to the one present in $\mathrm{fkh}\left[250^{\text {con }}\right]$. The lack of specific interactions seen in the crystal structures is consistent with the lack of specificity exhibited by this binding site both in vitro and in vivo. Perhaps when structures of Hox/Exd heterodimers bound to more selective binding sites (for example, Scr/Exd bound to fkh[250]) are available, specific contacts between the amino-terminal arm and the DNA will be visible. Another possibility is that the interactions between the amino-terminal arm and the DNA that are responsible for specificity may be too subtle to be seen in a crystal structure (Passner et al. 1999). A third possibility is that, at least in vivo, there are additional proteins that contribute to specificity that are not present in the crystal structures. At least one such additional factor may be Hth, which binds to DNA together with Hox/Exd heterodimers (H.D. Ryoo and R.S. Mann, in prep.). Although Hth binds together with and stabilizes the Hox/Exd heterodimers, it does not appear to contribute to Hox DNAbinding specificity (H.D. Ryoo and R.S. Mann, in prep.). There may be other factors in addition to Hth, Scr, and Exd that bind to fkh[250] and contribute to its specificity in vivo. Although at this time we cannot distinguish between these possibilities, it will be important to eventually understand how the Hox amino-terminal arm, in the context of a Hox/Exd heterodimer, achieves specificity at atomic resolution.

\section{Abd-A/Exd may be a repressor}

For some target genes, Hox proteins act as activators, whereas for other targets they act as repressors. One interesting observation made here is that Abd-A represses the $f k h\left[250^{c o n}\right]-l a c Z$ reporter gene, whereas Scr, Antp, and Ubx activate this same reporter. All four of these Hox proteins cooperatively bind this element with Exd in vitro. We suggest three explanations to account for these observations. In the first, all four Hox/Exd heterodimers would bind to $\mathrm{fkh}\left[250^{\mathrm{con}}\right]$ in vivo, but the Abd-A/Exd heterodimer acts as a transcriptional repressor, whereas the other Hox/Exd heterodimers act as activators. Similar to what was proposed for Dfd/Exd heterodimers (Li et al. 1999), Exd might reveal a latent repression domain in Abd-A. A second possibility suggests that the lack of $\mathrm{fkh}\left[250^{\mathrm{con}}\right]$ activation in the $a b d-A$ domain is due to inadequate amounts of nuclear Exd because of repression of hth by the abdominal Hox genes (Azpiazu and Morata 1998). This appears unlikely because overexpression of Exd and Hth in posterior segments was not sufficient to derepress $f k h\left[250^{\text {con }}\right]-l a c Z$ in the $a b d-A$ domain. A third possibility is that Abd-A/ Exd heterodimers do not directly activate or repress the $\mathrm{fkh}\left[250^{\mathrm{con}}\right]$ element, perhaps because the binding of this heterodimer is not stable in vivo. In this case, the lack of activation of fkh $\left[250^{c o n}\right]-l a c Z$ in the abd-A domain might be due to insufficient amounts of the activators Antp or $U b x$, which are normally down-regulated in the abdominal segments (Struhl and White 1985; White and
Wilcox 1985). One experiment that might help to resolve this question is to determine whether Abd-A/Exd heterodimers are directly bound to $\mathrm{fkh}\left[250^{\mathrm{con}}\right]$ in vivo.

\section{The subcellular localization of Exd modulates Hox activity}

Exd is regulated in an unusual manner for a homeodomain protein; during development, it is often found in the cytoplasm, and its nuclear localization is a regulated process (Mann and Abu-Shaar 1996; Aspland and White 1997; Abu-Shaar and Mann 1998; Abu-Shaar et al. 1999). When Exd is in the cytoplasm, it is nonfunctional as a Hox cofactor; therefore, any Hox target gene that requires activation by Hox/Exd heterodimers can be inactivated by shifting Exd from the nucleus to the cytoplasm. The nuclear localization of Exd requires the direct interaction with the homeodomain protein encoded by hth and it appears that most, if not all, of the regulation of Exd's nuclear localization is mediated indirectly by controlling $h t h$ transcription (Rieckhof et al. 1997; Abu-Shaar et al. 1999). Our experiments show that, by stage 11, Scr represses hth in PS 2, resulting in the cytoplasmic accumulation of its own cofactor, Exd. One consequence of this regulation is that Scr is no longer able to activate $f k h[250]$ and probably $f k h$, itself, later in development. The temporal regulation of Scr's ability to activate $f k h$ results in Scr being able to trigger a developmental program, such as salivary gland morphogenesis, although only being transiently expressed in that tissue. Once the $f k h$ gene is activated, it has the ability to positively autoregulate, thus ensuring its stable expression during the remainder of salivary gland development (L. Komenda and S. Beckendorf, pers. comm.). Conversely, in the absence of nuclear Exd, Scr is no longer able to activate $f k h$ in the remainder of PS 2, but instead probably controls other developmental pathways by activating different target genes. In these cells, in the absence of nuclear Exd, Scr may be using other, as yet unidentified, cofactors. Although no candidates are yet known, these putative cofactors will be important to identify in the future.

We suggest that the control of the nuclear localization of Exd, by regulating $h t h$ transcription, is a way to modulate Hox activity in vivo. In the presence of nuclear Exd, Scr is able to activate certain target genes, for example $f k h$. But Scr almost certainly regulates other target genes in an Exd-independent manner. Thus, the regulation of Exd's subcellular localization is a way to create two different versions of Scr-one that functions as an Scr/Exd heterodimer, and one that regulates target genes independently of Exd.

\section{The role of Exd in Hox function}

On the basis of the data presented here and elsewhere (Chan et al. 1997) we suggest that, at least for a subset of Hox/Exd-binding sites, Exd selectively enhances the DNA-binding of one Hox protein over another. Although 
there are likely to be other proteins that contribute to Hox specificity in vivo, we suggest that this aspect of Exd function is central to the mechanism by which different Hox proteins target different sets of downstream genes. The cooperativity between Hox and Exd illustrate an elegant example of combinatorial control in which the DNA sequence helps to assemble specific complexes between a generally expressed cofactor (Exd) and a family of related transcription factors (Hox) that have restricted expression patterns.

These results are also consistent with the alternative model proposed for Exd; that Exd modifies the transcriptional regulatory properties of the Hox proteins (Pinsonneault et al. 1997; Li et al. 1999). In principle, Exd could be providing both specificity and regulatory functions to the Hox proteins. However, if Exd is modifying the regulatory properties of the Hox proteins, it may be doing more than simply turning Hox proteins from repressors into activators (Biggin and McGinnis 1997; Pinsonneault et al. 1997). Instead, in part suggested by the data presented here, Exd might also help some Hox proteins be better repressors, or change the level of activation mediated by a particular Hox protein. In summary, we suggest that Exd probably serves both functions-to increase Hox DNA-binding specificity and modify Hox transcriptional regulatory properties-and that both mechanisms are critical for Hox function in vivo.

\section{Materials and methods}

\section{Fly stocks and transformants}

All fly stocks had the $w^{1118}$ mutation to monitor the presence of the mini-white gene in all P-element transgenes (Pirrotta 1988). P-element transformation was carried out by standard procedures. All reporter genes were generated by multimerizing four copies of $40 \mathrm{bp}$ in the same orientation, $37 \mathrm{bp}$ of which is from the original $f k h$ enhancer. A total of $3 \mathrm{bp}$ was added to make the junction GATC. For wild-type fkh[250], the 40-bp sequence is as follows: GATCTCAATGTCAagattaatcgCCAGCTGTGGGACGAGG, in which the underlined bases indicate the added linker sequence, and the small letters show the Scr/Exd-binding site (Fig. 1). Four copies of this element were required for sufficient levels of reporter gene activation (data not shown). Multimerized elements were blunted with klenow and ligated into a blunted SphI site of the CPLZ vector as described previously (Chan et al. 1997). For each reporter construct, the lacZ expression pattern was identical in multiple independent transformant lines.

The following Hox mutant chromosomes were used: $S c r^{2}$; $\mathrm{Scr}^{\mathrm{Cl}} \mathrm{Antp} \mathrm{Ns}^{\mathrm{Ns}+\mathrm{RC} 3}$; $\mathrm{Scr}^{\mathrm{Cl}} \mathrm{Antp}^{\mathrm{Ns}+\mathrm{RC} 3} \mathrm{Ubx}^{\mathrm{MX12}}$ (Struhl 1982); and $a b d-A^{\mathrm{M} 1} A b d-B^{\mathrm{M} 8}$ (Casanova et al. 1987). ex $d^{\text {mat }^{-}, \mathrm{zyg}^{-}}$embryos were generated as described (Rieckhof et al. 1997) by the FLP recombination system and the null allele exd $d^{\mathrm{XP11}}$. Mutant embryos were identified with either marked balancers, or by directly staining for mutant (absent) gene products. For analysis of ectopic Hox proteins with heat shock, the following lines were used: HS:Antp/FM7 (Jaffe et al. 1997), HS:Ubx (Mann and Hogness 1990), HS:Scr (Gibson et al. 1990), and the chimeric transgenes G26 and K26 (Furukubo-Tokunaga et al. 1993). Ectopic Hox expression by the Gal4-UAS system was carried out by the patched-Gal4 driver (Brand and Perrimon 1993) and the appropriate UAS:Hox transgene. fkh-lacZ used in Figure 1, D and E has been described previously and includes $5 \mathrm{~kb}$ of $f \mathrm{kh}$ regulatory DNA (Kuo et al. 1996).

\section{Antibody stainings}

HS:Hox embryos were collected for $3 \mathrm{hr}$, aged for $3 \mathrm{hr}$, and heat shocked at $37^{\circ} \mathrm{C}$ for the time required to make cuticle transformation, as was described previously for individual transgenes (Gibson et al. 1990; Mann and Hogness 1990; Furukubo-Tokunaga et al. 1993; Jaffe et al. 1997), and recovered for $2 \mathrm{hr}$ before fixation.

The anti- $\beta$-gal (Cappell), anti-Exd (Mann and Abu-Shaar 1996), anti-Scr (Pattatucci and Kaufman 1991), anti-Antp (Condie et al. 1991), and anti-Abd-A (Karch et al. 1990) antibodies have been described. Anti-Hth was either a chicken antibody (Casares and Mann 1998) or from guinea pigs, and directed against a full-length recombinant his-tagged Hth protein.

\section{EMSA}

EMSAs were carried out with his-tagged recombinant proteins synthesized in Escherichia coli and purified with $\mathrm{Ni}^{2+}$ chromatography (Chan and Mann 1996). his-Antp (Jaffe et al. 1997) and his-Exd (Chan et al. 1997) were described previously. his-Scr protein is nearly full length (amino acids 2-404) fused to the his tag in the pQE31 vector (Qiagen). His-Ubx protein (isoform Ia) is from amino acid 57 to its carboxyl terminus fused to the his tag in the pQE9 vector (Qiagen). his-Abd-A protein is from amino acid 79 to its carboxyl terminus fused to the his tag of the pET14b vector (Novagen). Oligos for EMSAs were identical to those used to make reporter constructs and were not multimerized. Oligos were end labeled with $\left[{ }^{32} \mathrm{P}\right] \mathrm{dCTP}$ and gel purified. For all EMSAs, each Hox protein was tested at two concentrations, in the presence and absence of Exd: for Scr, Ubx, and Abd-A these were $10 \mathrm{ng}$ and $30 \mathrm{ng}$; for Antp these were $30 \mathrm{ng}$ and $90 \mathrm{ng}$. The amount of Exd used was $80 \mathrm{ng}$.

\section{Acknowledgments}

We thank S. Beckendorf and L. Komenda for sharing with us the sequence of $\mathrm{fkh}[250]$ and for first recognizing the presence of a potential Hox/Exd-binding site. We thank W. Gehring, L. Pick, R. White, and the Bloomington Stock Center for reagents or fly stocks and D. Andrew, S. Beckendorf, and L. Komenda for sharing unpublished results. We are indebted to members of the Mann laboratory for discussions and comments throughout this work, C. Tomkins for embryo injections, and A. Aggarwal, T. Jessell, J. Passner, and D. Thanos for comments on the manuscript. This work was supported by an National Institutes of Health grant to R.S.M., who is a Scholar of the Leukemia Society of America.

The publication costs of this article were defrayed in part by payment of page charges. This article must therefore be hereby marked 'advertisement' in accordance with 18 USC section 1734 solely to indicate this fact.

\section{References}

Abu-Shaar, M. and R.S. Mann. 1998. Generation of multiple antagonistic domains along the proximodistal axis during Drosophila leg development. Development 125: 3821-3830.

Abu-Shaar, M., H.D. Ryoo, and R.S. Mann. 1999. Control of the nuclear localization of Extradenticle by competing localization and export signals. Genes \& Dev. 13: 935-945.

Andrew, D.J. 1998. Regulation and formation of the Drosophila salivary glands. Ann. N.Y. Acad. Sci. 15: 55-69. 
Aspland, S.E. and R.A. White. 1997. Nucleocytoplasmic localisation of extradenticle protein is spatially regulated throughout development in Drosophila. Development 124: 741-747.

Azpiazu, N. and G. Morata. 1998. Functional and regulatory interactions between Hox and extradenticle genes. Genes \& Dev. 12: 261-273.

Biggin, M. and W. McGinnis. 1997. Regulation of segmentation and segmental identity by Drosophila homeoproteins: The role of DNA-binding in functional activity and specificity. Development 124: 4425-4433.

Brand, A. and N. Perrimon. 1993. Targeted gene expression as a means of altering cell fates and generating dominant phenotypes. Development 118: 401-415.

Burglin, T.R. and G. Ruvkun. 1992. New motif in PBX genes. Nat. Genet. 1: 319-320.

Carr, A. and M.D. Biggin. 1999. A comparison of in vivo and in vitro DNA-binding specificities suggests a new model for homeoprotein DNA-binding in Drosophila embryos. EMBO J. 18: 1598-1608.

Casanova, J., E. Sanchez-Herrero, A. Busturia, and G. Morata. 1987. Double and triple mutant combinations of the bithorax complex of Drosophila. EMBO J. 6: 3103-3109.

Casares, F. and R.S. Mann. 1998. Control of antennal versus leg development in Drosophila. Nature 392: 723-726.

Chan, S.-K. and R.S. Mann. 1993. The segment identity functions of Ultrabithorax are contained within its homeo domain and carboxy-terminal sequences. Genes \& Dev. 7: 796-811.

- 1996. A structural model for an extradenticle-HOXDNA complex accounts for the choice of HOX protein in the heterodimer. Proc. Natl. Acad. Sci. 93: 5223-5228.

Chan, S.-K., H.D. Ryoo, L. Jaffe, M. Capovilla, J. Botas, and R.S. Mann. 1994. The DNA binding specificity of ultrabithorax is modulated by cooperative interactions with extradenticle, another homeoprotein. Cell 78: 603-615.

Chan, S.-K., H. Pöpperl, R. Krumlauf, and R.S. Mann. 1996. An extradenticle-induced conformational change in a HOX protein overcomes an inhibitory function of the conserved hexapeptide motif. EMBO J. 15: 2477-2488.

Chan, S.-K., A. Gould, R. Krumlauf, and R. Mann. 1997. Switching the in vivo specificity of a minimal Hox-responsive element. Development 124: 2007-2014.

Chang, C.-P., L. Brocchieri, W.-F. Shen, C. Largman, and M. Cleary. 1996. Pbx modulation of hox homeodomain aminoterminal arms establishes different DNA-binding specificities across the HOX locus. Mol. Cell. Biol. 16: 1734-1745.

Condie, J.M., J.A. Mustard, and D. Brower. 1991. Generation of anti-Antennapedia monoclonal antibodies and Antennapedia protein expression in imaginal discs. Dros. Inf. Serv. 70: $52-54$.

Dearolf, C.R., J. Ropol, and C.S. Parker. 1989. The caudal gene product is a direct activator of fushi tarazu transcription during Drosophila embryogenesis. Nature 341: 340-343.

Ekker, S.C., D.G. Jackson, D.P. von Kessler, B.I. Sun, K.E. Young, and P.A. Beachy. 1994. The degree of variation in DNA sequence recognition among four Drosophila homeotic proteins. EMBO J. 13: 3551-3560.

Fraenkel, E. and C.O. Pabo. 1998. Comparison of X-ray and NMR structures for the Antennapedia homeodomain-DNA complex. Nat. Struct. Biol. 5: 692-697.

Furukubo-Tokunaga, K., S. Flister, and W.J. Gehring. 1993. Functional specificity of the Antennapedia homeodomain. Proc. Nat1. Acad. Sci. 90: 6360-6364.

Gibson, G., A. Schier, P. LeMotte, and W.J. Gehring. 1990. The specificities of Sex combs reduced and Antennapedia are defined by a distinct portion of each protein that includes the homeodomain. Cell 62: 1087-1103.
Gonzalez-Crespo, S. and G. Morata. 1995. Control of Drosophila adult pattern by extradenticle. Development 121: $2117-2125$.

Graba, Y., D. Aragnol, and J. Pradel. 1997. Drosophila Hox complex downstream targets and the function of homeotic genes. BioEssays 19: 379-388.

Grieder, N., T. Marty, H.-D. Ryoo, R.S. Mann, and M. Affolter. 1997. Synergistic activation of a Drosophila enhancer by HOM/EXD and DPP signaling. EMBO J. 16: 7402-7410.

Hirsch, J. and A. Aggarwal. 1995. Structure of the Even-skipped homeodomain complexed to AT-rich DNA: New perspectives on homeodomain specificity. EMBO J. 14: 6280-6291.

Jaffe, L., H.D. Ryoo, and R.S. Mann. 1997. A role for phosphorylation by casein kinase 2 in modulating Antennapedia function in Drosophila. Genes \& Dev. 11: 1327-1340.

Karch, F., W. Bender, and B. Weiffenbach. 1990. abdA expression in Drosophila embryos. Genes \& Dev. 4: 1573-1587.

Kissinger, C.R., B. Liu, E. Martin-Blanco, T.B. Kornberg, and C.O. Pabo. 1990. Crystal structure of an engrailed homeodomain-DNA complex at $2.8 \AA$ resolution: A framework for understanding homeodomain-DNA interactions. Cell 63: 579_590.

Knoepfler, P. and M. Kamps. 1995. The pentapeptide motif of Hox proteins is required for cooperative DNA binding with $\mathrm{Pbx1}$, physically contacts $\mathrm{Pbx1}$, and enhances DNA binding by Pbx1. Mol. Cell. Biol. 15: 5811-5819.

Kuo, Y.M., N. Jones, B. Zhou, S. Panzer, V. Larson, and S.K. Beckendorf. 1996. Salivary duct determination in Drosophila: Roles of the EGF receptor signalling pathway and the transcription factors fork head and trachealess. Development 122: 1909-1917.

Kuziora, M.A. and W. McGinnis. 1989. A homeodomain substitution changes the regulatory specificity of the deformed protein in Drosophila embryos. Cell 59: 563-571.

Li, X., C. Murre, and W. McGinnis. 1999. Activity regulation of a Hox protein and a role for the homeodomain in inhibiting transcriptional activation. EMBO I. 18: 198-211.

Liang, Z. and M.D. Biggin. 1998. Eve and Ftz regulate a wide array of genes in blastoderm embryos: The selector homeoproteins directly or indirectly regulate most genes in Drosophila. Development 125: 4471-4482.

Lin, L. and W. McGinnis. 1992. Mapping functional specificity in the Dfd and Ubx homeo domains. Genes \& Dev. 6: 10711081.

Lu, Q., P. Knoepfler, J. Scheele, D. Wright, and M. Kamps. 1995. Both Pbxl and E2A-Pbx1 bind the DNA motif ATCAATCAA cooperatively with the products of multiple murine Hox genes, some of which are themselves oncogenes. Mol. Cell. Biol. 15: 3786-3795.

Macdonald, P.M. and G. Struhl. 1986. A molecular gradient in early Drosophila embryos and its role in specifying the body pattern. Nature 324: 537-545.

Mann, R.S. and D.S. Hogness. 1990. Functional dissection of Ultrabithorax proteins in D. melanogaster. Cell 60: 597-610.

Mann, R. and M. Abu-Shaar. 1996. Nuclear import of the homeodomain protein Extradenticle in response to Decapentaplegic and Wingless signalling. Nature 383: 630-633.

Mann, R.S. and S.-K. Chan. 1996. Extra specificity from extradenticle: The partnership between HOX and exd/Pbx homeodomain proteins. Trends Genet. 12: 258-262.

McGinnis, W. and R. Krumlauf. 1992. Homeobox genes and axial patterning. Cell 68: 283-302.

Mlodzik, M. and W.J. Gehring. 1987. Expression of the caudal gene in the germ line of Drosophila: Formation of an RNA and protein gradient during early embryogenesis. Cell 48: $465-478$ 
Neuteboom, S.T. and C. Murre. 1997. Pbx raises the DNA-binding specificity but not the selectivity of antennapedia Hox proteins. Mol. Cell. Biol. 17: 4696-4706.

Pai, C.-Y., T. Kuo, T. Jaw, E. Kurant, C. Chen, D. Bessarab, A. Salzberg, and Y. Sun. 1998. The Homothorax homeoprotein activates the nuclear localization of another homeoprotein, extradenticle, and suppresses eye development in Drosophila. Genes \& Dev. 12: 435-446.

Panzer, S., D. Weigel, and S.K. Beckendorf. 1992. Organogenesis in Drosophila melanogaster: Embryonic salivary gland determination is controlled by homeotic and dorsoventral patterning genes. Development 114: 49-57.

Passner, J.M., H.D. Ryoo, L. Shen, R.S. Mann, and A.K. Aggarwal. 1999. Structure of a DNA-bound Ultrabithorax-Extradenticle homeodomain complex. Nature 397: 714-718.

Pattatucci, A.M. and T.C. Kaufman. 1991. The homeotic gene Sex combs reduced of Drosophila melanogaster is differentially regulated in the embryonic and imaginal stages of development. Genetics 129: 443-461.

Peifer, M. and E. Wieschaus. 1990. Mutations in the Drosophila gene extradenticle affect the way specific homeo domain proteins regulate segmental identity. Genes \& Dev. 4: 1209_ 1223.

Percival-Smith, A., J. Weber, E. Gilfoyle, and P. Wilson. 1998. Genetic characterization of the role of the two HOX proteins, Proboscipedia and Sex Combs Reduced, in determination of adult antennal, tarsal, maxillary palp and proboscis identities in Drosophila melanogaster. Development 124: 5049-5062.

Phelan, M.L. and M.S. Featherstone. 1997. Distinct HOX amino-terminal arm residues are responsible for specificity of DNA recognition by HOX monomers and HOX.PBX heterodimers. J. Biol. Chem. 272: 8635-8643.

Phelan, M.L., R. Sadoul, and M.S. Featherstone. 1994. Functional differences between HOX proteins conferred by two residues in the homeodomain amino-terminal arm. Mol. Cell. Biol. 14: 5066-5075.

Pinsonneault, J., B. Florence, H. Vaessin, and W. McGinnis. 1997. A model for extradenticle function as a switch that changes HOX proteins from repressors to activators. $E M B O$ J. 16: 2032-2042.

Piper, D.E., A.H. Batchelor, C.-P. Chang, M.L. Cleary, and C. Wolberger. 1999. Structure of a HoxB1-Pbx1 heterodimer bound to DNA: Role of the hexapeptide and a fourth homeodomain helix in complex formation. Cell 96: 587-597.

Pirrotta, V. 1988. Vectors for P-mediated transformation in Drosophila. In Vectors, a survey of molecular cloning vectors their uses (ed. R.L. Rodriguez and D.T. Denhardt), pp. 437456. Butterworth, Boston, MA.

Pöpperl, H., M. Bienz, M. Studer, S.-K. Chan, S. Aparicio, S. Brenner, R. Mann, and R. Krumlauf. 1995. Segmental expression of Hoxb-1 is controlled by a highly conserved autoregulatory loop dependent upon exd/Pbx. Cell 81: 1031-1042.

Rauskolb, C. and E. Wieschaus. 1994. Coordinate regulation of downstream genes by extradenticle and the homeotic selector proteins. EMBO J. 13: 3561-3569.

Rauskolb, C., M. Peifer, and E. Wieschaus. 1993. extradenticle, a regulator of homeotic gene activity, is a homolog of the homeobox-containing human proto-oncogene pbx1. Cell 74: $1-20$.

Rauskolb, C., K. Smith, M. Peifer, and E. Wieschaus. 1995. extradenticle determines segmental identities throughout development. Development 121: 3663-3671.

Rieckhof, G., F. Casares, H.D. Ryoo, M. Abu-Shaar, and R.S. Mann. 1997. Nuclear translocation of Extradenticle requires homothorax, which encodes an Extradenticle-related homeodomain protein. Cell 91: 171-183.

Shen, W.F., C.P. Chang, S. Rozenfeld, G. Sauvageau, R.K. Humphries, M. Lu, H.J. Lawrence, M.L. Cleary, and C. Largman. 1996. Hox homeodomain proteins exhibit selective complex stabilities with Pbx and DNA. Nucleic Acids Res. 24: 898-906.

Struhl, G. 1982. Genes controlling segmental specification in the Drosophila thorax. Proc. Natl. Acad. Sci. 79: 7380-7384.

Struhl, G. and R.A. White. 1985. Regulation of the Ultrabithorax gene of Drosophila by other bithorax complex genes. Cell 43: 507-519.

Walter, J., C. Dever, and M.D. Biggin. 1994. Two homeodomain proteins bind with similar specificity to a wide range of DNA sites in Drosophila embryos. Genes \& Dev. 8: 16781692.

White, R.A.H. and M. Wilcox. 1985. Distribution of Ultrabithorax proteins in Drosophila. EMBO J. 4: 2035-2043.

Wilson, D. and C. Desplan. 1999. The structural basis for Hox specificity revealed: A molecular 'menage-â-trois'. Nat. Struct. Biol. 6: 297-300.

Wolberger, C., A.K. Vershon, B. Liu, A.D. Johnson, and C.O. Pabo. 1991. Crystal structure of a MAT alpha 2 homeodomain-operator complex suggests a general model for homeodomain-DNA interactions. Cell 67: 517-528.

Zeng, W., D.J. Andrew, L.D. Mathies, M.A. Horner, and M.P. Scott. 1993. Ectopic expression and function of the Antp and Scr homeotic genes: The $\mathrm{N}$ terminus of the homeodomian is critical to functional specificity. Development 118: 339-352. 


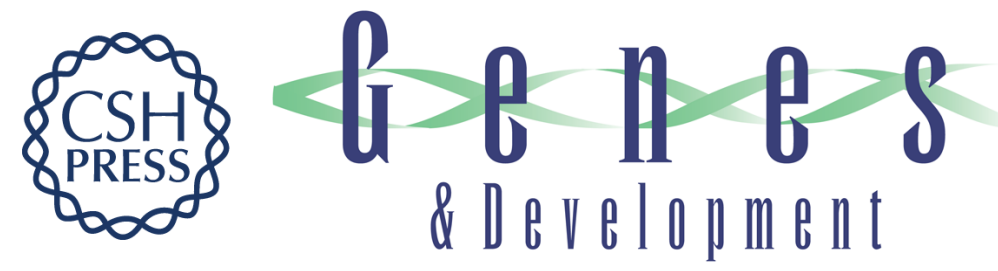

\section{The control of trunk Hox specificity and activity by Extradenticle}

Hyung Don Ryoo and Richard S. Mann

Genes Dev. 1999, 13:

References This article cites 66 articles, 35 of which can be accessed free at: http://genesdev.cshlp.org/content/13/13/1704.full.html\#ref-list-1

License

Email Alerting Receive free email alerts when new articles cite this article - sign up in the box at the top Service right corner of the article or click here.

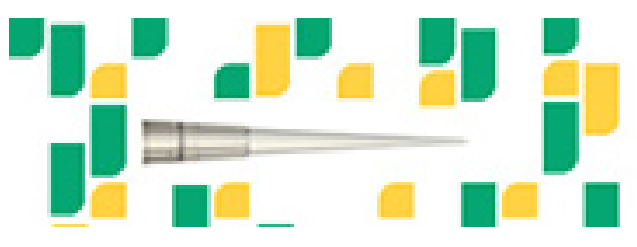

Focused on your science. 